\title{
Hydrogenimonas thermophila gen. nov., sp. nov., a novel thermophilic, hydrogen-oxidizing chemolithoautotroph within the $\varepsilon$-Proteobacteria, isolated from a black smoker in a Central Indian Ridge hydrothermal field
}

\author{
Ken Takai, ${ }^{1}$ Kenneth H. Nealson ${ }^{1,2}$ and Koki Horikoshi ${ }^{1}$ \\ ${ }^{1}$ Subground Animalcule Retrieval (SUGAR) Project, Frontier Research System for \\ Extremophiles, Japan Marine Science and Technology Centre, 2-15 Natsushima-cho, \\ Yokosuka 237-0061, Japan \\ ${ }^{2}$ Department of Earth Sciences, University of Southern California, 3651 Trousdale Parkway, \\ Los Angeles, CA 90089-0740, USA
}

\begin{abstract}
A novel thermophilic bacterium, strain EP1-55-1\% ${ }^{\top}$, was isolated from an in-situ colonization system deployed in a superheated, deep-sea, hydrothermal vent emission at the Kairei Field on the Central Indian Ridge in the Indian Ocean. The cells were highly motile rods, each possessing a single polar flagellum. Growth was observed between 35 and $65^{\circ} \mathrm{C}$ (optimum temperature, $55^{\circ} \mathrm{C} ; 70$ min doubling time) and between $\mathrm{pH} 4.9$ and $7 \cdot 2$ (optimum, $\mathrm{pH} 5.9$ ). The isolate was a microaerobic-to-anaerobic chemolithoautotroph capable of using molecular hydrogen as the sole energy source and carbon dioxide as the sole carbon source. Molecular oxygen, nitrate or elemental sulfur $\left(S^{0}\right)$ could serve as electron acceptors to support growth. The $G+C$ content of the genomic DNA was 34.6 mol\%. Phylogenetic analysis based on 16S rDNA sequences indicated that strain EP1-55-1\% $\%^{\top}$ represents the first strain for which taxonomic properties have been characterized within the previously uncultivated phylogroup classified as belonging to the uncultivated $\varepsilon$-Proteobacteria group $\mathrm{A}$; the name Hydrogenimonas thermophila gen. nov., sp. nov. is proposed, with strain EP1-55-1\% $\%^{\top}\left(=\mathrm{JCM} 11971^{\top}=\right.$ ATCC BAA-737 $\left.{ }^{\top}\right)$ as the type strain.
\end{abstract}

During the last decade, molecular phylogenetic surveys of microbial ecosystems in global deep-sea hydrothermal systems have revealed a great diversity of micro-organisms inhabiting niches associated with steep physical and geochemical gradients (Takai \& Fujiwara, 2002). In hightemperature habitats adjacent to hot, anoxic hydrothermal fluids, anaerobic, hyperthermophilic members of the Archaea and the Bacteria dominate the microbial communities, while, at lower temperatures, the predominant microbial components are psychrophilic and aerobic entities (Takai \& Fujiwara, 2002). Analyses, using smallsubunit rRNA gene (rDNA) sequences, of microbial communities in near-vent environments have revealed the predominance and diversity of previously uncultivated

Published online ahead of print on 13 June 2003 as DOI 10.1099/ ijs.0.02787-0.

The GenBank/EMBL/DDBJ accession number for the $16 \mathrm{~S}$ rDNA sequence of strain $\mathrm{EP} 1-55-1 \%{ }^{\top}$ is $\mathrm{AB} 105049$.

Details of the effects of temperature, $\mathrm{pH}$ and $\mathrm{NaCl}$ concentration on the growth of strain EP1-55-1\% $\%^{\top}$ are available as supplementary data in IJSEM Online. members of the $\varepsilon$-Proteobacteria (Cary et al., 1997; Corre et al., 2001; Longnecker \& Reysenbach, 2001; Moyer et al., 1995; Reysenbach et al., 2000). However, their physiology has remained unclear because of their resistance to cultivation.

Recently, isolation and characterization of previously uncultivated members of the $\varepsilon$-Proteobacteria have been reported (Campbell et al., 2001; Miroshnichenko et al., 2002; Alain et al., 2002). Nautilia lithotrophica strain $525^{\mathrm{T}}$ (Miroshnichenko et al., 2002) and Caminibacter hydrogeniphilus strain $\mathrm{AM}_{1116^{\mathrm{T}}}$ (Alain et al., 2002) were identified as novel strictly anaerobic, hydrogen-oxidizing, thermophilic chemolithomixotrophs from the nests of tube-dwelling polychaetes in deep-sea hydrothermal systems in the East-Pacific Rise. Other isolates (strains Am-H and EX-18.2) from similar habitats were reported as slightly thermophilic, anaerobic mixotrophs capable of using hydrogen as an energy source and elemental sulfur as a primary electron acceptor (Campbell et al., 2001). These isolates represented the first cultivated members of the $\varepsilon$-Proteobacteria of previously uncultivated group $\mathrm{D}$, one 
of the phylogenetic groups within the $\varepsilon$-Proteobacteria according to the classification by Corre et al. (2001). Our laboratory has recently cultivated and partially characterized many isolates of the $\varepsilon$-Proteobacteria, representing nearly all of the previously uncultivated subgroups inhabiting deep-sea hydrothermal environments (Takai et al., 2003a). In the investigation, thiosulfate and elemental sulfur as well as molecular hydrogen were provided together as energy sources together with molecular oxygen and nitrate as electron acceptors, which are more abundant than elemental sulfur in the ambient habitats of deep-sea hydrothermal systems (Takai et al., 2003a). On the basis of its partial $16 \mathrm{~S}$ rDNA sequence, one of the thermophilic strains, designated EP1-55-1\% ${ }^{\mathrm{T}}$, was phylogenetically affiliated with the uncultivated $\varepsilon$-Proteobacteria group A, a thermophilic lineage completely different from the previously described N. lithotrophica $525^{\mathrm{T}}$ (Miroshnichenko et al., 2002) and C. hydrogeniphilus $\mathrm{AM}_{116^{\mathrm{T}}}$ (Alain et al., 2002). Here, we report a taxonomic study and the partial characterization of strain EP1-55-1\% ${ }^{\mathrm{T}}$ and propose the new genus Hydrogenimonas.

\section{Sample collection, enrichment and purification}

Sample collection and subsampling procedures were as described previously (Takai et al., 2003a). An in-situ colonization system, a new artificial microbial habitat consisting of a stainless steel pipe with many small holes $(5 \mathrm{~mm}$ in diameter) and a substratum of very porous, natural and synthetic pumice (Takai et al., 2003a), was deployed for 3 days in a black smoker vent orifice with a vent emission temperature of $>250{ }^{\circ} \mathrm{C}$ at the Kairei Field on the Central Indian Ridge $\left(25^{\circ} 19 \cdot 23^{\prime} \mathrm{S}, 70^{\circ} 02 \cdot 42^{\prime} \mathrm{E}\right)$, at a depth of $2421 \mathrm{~m}$. After deployment, it was recovered by the manned submersible Shinkai 6500. The Kairei hydrothermal field on the Central Indian Ridge of the Indian Ocean was discovered for the first time by Japanese scientists in 2000 (Hashimoto et al., 2001), and the physical and chemical characterization of the vent emissions was described elsewhere (Gamo et al., 2001). The substratum of the in-situ colonization system was suspended in $20 \mathrm{ml}$ sterilized MJ synthetic sea water (Sako et al., 1996; Takai et al., 1999) containing 0.05\% (w/v) sodium sulfide in a $100 \mathrm{ml}$ glass bottle (Schott Glaswerke) tightly sealed with a butyl-rubber cap under a gas phase of $100 \% \mathrm{~N}_{2}(100 \mathrm{kPa})$. The suspended slurry was used to inoculate a series of media, including MMJHS medium (Takai et al., 2003a), under a gas phase of $\mathrm{H}_{2} / \mathrm{CO}_{2} / \mathrm{O}_{2}$ $(80: 19: 1$, by vol.; $300 \mathrm{kPa})$, and the cultures were incubated at $55^{\circ} \mathrm{C}$ in a dry oven.

Growth of thermophiles was observed in MMJHS medium after 2 days incubation at $55^{\circ} \mathrm{C}$. Enrichment cultures at $55^{\circ} \mathrm{C}$ contained rod-shaped cells. A pure culture was obtained by using the dilution-to-extinction technique at $55^{\circ} \mathrm{C}$ with the same medium as that used for the enrichment (Takai \& Horikoshi, 2000). The culture in the tube showing growth at the highest dilution was designated strain EP1-55-1\% ${ }^{\mathrm{T}}\left(=\mathrm{JCM} 11971^{\mathrm{T}}=\right.$ ATCC BAA- $\left.737^{\mathrm{T}}\right)$. Purity was confirmed routinely by microscopic examination and by repeated partial sequencing of the 16S rRNA gene using several PCR primers.

\section{Morphology}

Cells were observed under a phase-contrast Olympus BX51 microscope with the SPOT RT Slider CCD camera system (Diagnostic Instruments). Transmission electron microscopy of negatively stained cells and thin sections of cells was carried out as described by Zillig et al. (1990) and Takai et al. (1999). Cells grown in MMJH medium (described below) under microaerobic conditions ( $1 \%$ partial pressure of $\mathrm{O}_{2}$ ) at $55^{\circ} \mathrm{C}$ in the mid-exponential phase of growth were used for microscopic observation. Cells of strain EP1-55-1\% ${ }^{\mathrm{T}}$ were Gram-negative rods, about $0 \cdot 7-1 \cdot 0 \mu \mathrm{m}$ in diameter, $1 \cdot 5-3 \cdot 5 \mu \mathrm{m}$ long (Fig. 1a, c) and highly motile by means of a polar flagellum (Fig. 1a). When strain EP1$55-1 \%$ was grown in MMJH medium under anaerobic conditions, cells became uniformly non-motile and spherical in the stationary phase. A small percentage of cells grown under microaerobic conditions also exhibited this spherical shape (Fig. 1b) in the stationary phase. Although similar morphological features were reported for N. lithotrophica $525^{\mathrm{T}}$ (Miroshnichenko et al., 2002) and C. hydrogeniphilus AM1116 ${ }^{\mathrm{T}}$ (Alain et al., 2002) (Table 1), the formation of a spherical cell shape in strain EP1-55-1\% ${ }^{\mathrm{T}}$ was a distinctive morphological feature with respect to these previously described thermophilic e-proteobacterial genera.

\section{Growth characteristics}

Strain EP1-55-1\% was routinely cultivated in MMJH medium. MMJH medium was MMJ medium (Takai et al., 2002) supplemented with $5 \mathrm{mM}$ calcium chloride $\left(\mathrm{CaCl}_{2}\right)$ and $10 \mathrm{mM}$ sodium nitrate $\left(\mathrm{NaNO}_{3}\right)$ without sodium sulfide $\left(\mathrm{Na}_{2} \mathrm{~S} .9 \mathrm{H}_{2} \mathrm{O}\right)$ or cysteine hydrochloride. To prepare the medium, everything except the vitamin solution (Balch et al., 1979) and $\mathrm{NaHCO}_{3}$ was dissolved and the $\mathrm{pH}$ of the medium was adjusted to around $6 \cdot 0$ with $\mathrm{HCl}$ before autoclaving. After autoclaving under an air atmosphere, a concentrated solution of vitamins and $\mathrm{NaHCO}_{3}$ was added to the medium under gas purging with $\mathrm{H}_{2} / \mathrm{CO}_{2}(80: 20$, $\mathrm{v} / \mathrm{v}$ ), and the $\mathrm{pH}$ was readjusted to 6.0 with $\mathrm{HCl}$ at room temperature, if necessary. A concentrated sodium bicarbonate solution was separately sterilized by autoclaving, and the vitamin solution was filter-sterilized. The medium was dispensed to $20 \%$ of the bottle (Schott Glaswerke) or tube (Iwaki Glass) volume and tightly sealed with a butyl-rubber stopper under a gas phase of $\mathrm{H}_{2} / \mathrm{CO}_{2} / \mathrm{O}_{2}(80: 19: 1$, by vol.) at $300 \mathrm{kPa}$ unless otherwise noted.

Growth of strain EP1-55-1\% ${ }^{\mathrm{T}}$ was measured by direct cell counting after staining with $4^{\prime}$,6-diamidino-2-phenylindole (Porter \& Feig, 1980) using a phase-contrast Olympus BX51 microscope. Cultures were prepared in duplicate in $100 \mathrm{ml}$ glass bottles (Schott Glaswerke), each containing $20 \mathrm{ml}$ medium, with shaking (100 r.p.m.) in a temperaturecontrolled dry oven. With MMJH medium, strain EP1-55$1 \%^{\mathrm{T}}$ grew over the temperature range of about $35-65^{\circ} \mathrm{C}$, 

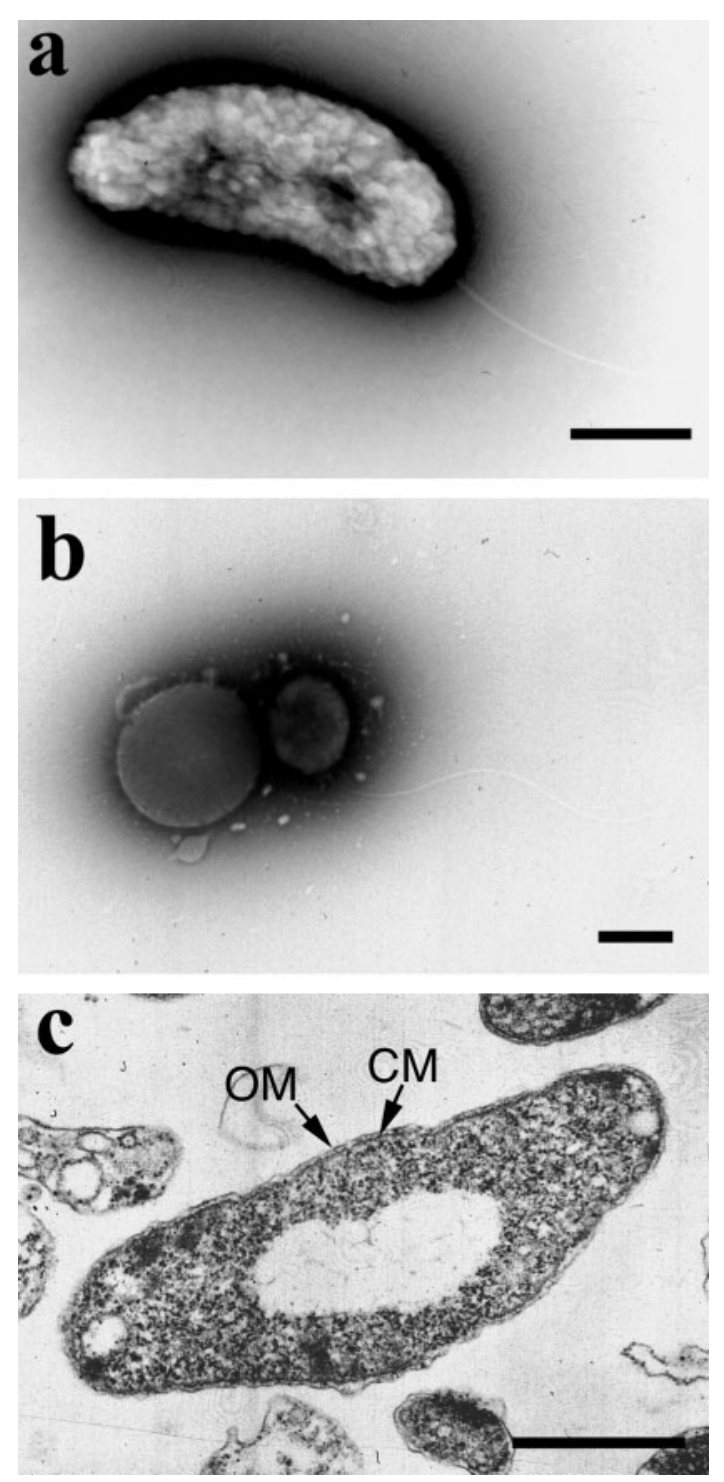

Fig. 1. Electron micrographs of a negatively stained cell $(a, b)$ and a thin-section of a cell (c) of strain EP1-55-1\% $\%^{\top}$. (a, c) Rod cell in the mid-exponential phase of growth. (b) Spherical cells observed in the stationary phase of culture under anaerobic conditions. CM, Cellular membrane; OM, outer membrane. Bars, $0.5 \mu \mathrm{m}$.

showing optimal growth at $55^{\circ} \mathrm{C}$, and the generation time at $55^{\circ} \mathrm{C}, \mathrm{pH} 6 \cdot 0$, was about $70 \mathrm{~min}$ (see Supplementary Figure in IJSEM Online). The effect of $\mathrm{pH}$ on growth was tested at $55^{\circ} \mathrm{C}$, using $\mathrm{MMJH}$ medium adjusted to various values with $10 \mathrm{mM}$ acetate/acetic acid buffer ( $\mathrm{pH} 4-5)$, MES (pH 5-6), PIPES (pH 6-7), HEPES (pH 7-7·5) and Tris ( $\mathrm{pH} 8-9 \cdot 5)$ at room temperature (Supplementary Figure). Growth occurred at $\mathrm{pH} 4 \cdot 9-7 \cdot 2$, with optimum growth at about pH 5.9 (Supplementary Figure). No growth was observed below $\mathrm{pH} 4 \cdot 5$ or above $\mathrm{pH} 7 \cdot 7$. The $\mathrm{pH}$ was found to be stable during the cultivation period. Strain EP1-55-1\% ${ }^{\mathrm{T}}$, when tested in MMJH medium with variable amounts of added $\mathrm{NaCl}$, grew at $\mathrm{NaCl}$ concentrations in the range $16-56 \mathrm{~g} \mathrm{l}^{-1}$, with optimum growth at $32 \mathrm{~g} \mathrm{l}^{-1} \mathrm{NaCl}$ at $55^{\circ} \mathrm{C}$ and $\mathrm{pH} 6 \cdot 0$ (Supplementary Figure). In general, the temperature and salt requirements of EP1-55-1\% $\%^{\mathrm{T}}$ were similar to those of $N$. lithotrophica $525^{\mathrm{T}}$ (Miroshnichenko et al., 2002) and C. hydrogeniphilus AM1116 ${ }^{\mathrm{T}}$ (Alain et al., 2002) (Table 1).

The effect of the oxygen concentration in the gas phase on growth of strain EP1-55-1\% ${ }^{\mathrm{T}}$ was tested with $\mathrm{MMJH}$ medium under the following gas mixtures (at $300 \mathrm{kPa}$, all by volume): $\mathrm{H}_{2} / \mathrm{CO}_{2}, 80: 20 ; \mathrm{H}_{2} / \mathrm{CO}_{2} / \mathrm{O}_{2}, 80: 19 \cdot 9: 0 \cdot 1 ; \mathrm{H}_{2} /$ $\mathrm{CO}_{2} / \mathrm{O}_{2}, 80: 19 \cdot 5: 0 \cdot 5 ; \mathrm{H}_{2} / \mathrm{CO}_{2} / \mathrm{O}_{2}, 80: 19: 1 ; \mathrm{H}_{2} / \mathrm{CO}_{2} / \mathrm{O}_{2}$, $80: 18: 2$; or $\mathrm{H}_{2} / \mathrm{CO}_{2} / \mathrm{O}_{2}, 80: 17: 3$. The maximum cell yield of strain EP1-55-1\% ${ }^{\mathrm{T}}$ was approximately $3 \times 10^{9} \mathrm{cells}^{-1}$ under a gas phase in the absence or presence of up to $1 \%$ $\mathrm{O}_{2}$; a slightly lower yield $\left(8 \times 10^{8}\right.$ cells $\left.\mathrm{ml}^{-1}\right)$ was seen with $2 \% \mathrm{O}_{2}$. No growth was observed with $3 \% \mathrm{O}_{2}$ in the gas phase. These results indicated that strain EP1-55-1\% ${ }^{\mathrm{T}}$ grows under anaerobic-to-microaerobic (up to $2 \% \mathrm{O}_{2}$ ) conditions.

Heterotrophic growth was tested in $\mathrm{MMJH}$ medium without $\mathrm{NaHCO}_{3}$ under a gas phase of $\mathrm{H}_{2} / \mathrm{O}_{2}$ (99: 1, v/v; $300 \mathrm{kPa}$ ), containing the following potential carbon sources: yeast extract, peptone, tryptone, Casamino acids (all $0.2 \%$, $\mathrm{w} / \mathrm{v})$, formate, acetate, glycerol (all $5 \mathrm{mM}), 0.025 \%(\mathrm{v} / \mathrm{v})$ methanol, $0 \cdot 05 \%(\mathrm{v} / \mathrm{v})$ ethanol, $0 \cdot 1 \%(\mathrm{v} / \mathrm{v})$ 2-propanol, citrate, tartrate, fumarate, malate, succinate, propionate, maleate, lactate, oxalate, thioglycolate, pyruvate (all $5 \mathrm{mM}$ ), $5 \mathrm{mM}$ of each of 20 amino acids, glucose, galactose, sucrose, fructose, lactose, maltose, arabinose, trehalose and starch (all $0 \cdot 1 \%, w / v)$. Strain EP1-55-1\% ${ }^{\mathrm{T}}$ was not able to grow with any of the heterotrophic substrates, using $\mathrm{H}_{2}$ as an energy source and nitrate or molecular oxygen as an electron acceptor.

Utilization of these organic compounds as alternative energy sources instead of $\mathrm{H}_{2}$ was also examined in $\mathrm{MMJH}$ medium under a gas phase of $\mathrm{N}_{2} / \mathrm{CO}_{2} / \mathrm{O}_{2}(80: 19: 1$, by vol.; $300 \mathrm{kPa})$. None of the organic compounds sustained growth of strain EP1-55-1\% ${ }^{\mathrm{T}}$. In an attempt to determine potential electron donors other than $\mathrm{H}_{2}$ for autotrophic growth, sulfide ( 5 or $20 \mathrm{mM})$, thiosulfate $(20 \mathrm{mM})$, sulfite (5 or $20 \mathrm{mM})$, elemental sulfur $(3 \%, \mathrm{w} / \mathrm{v})$ and ferrous iron $(20 \mathrm{mM})$ were tested instead of $\mathrm{H}_{2}$ as sole electron donors in $\mathrm{MMJH}$ medium with a gas phase of $\mathrm{N}_{2} / \mathrm{CO}_{2} / \mathrm{O}_{2}$ $(80: 19: 1$, by vol.; $300 \mathrm{kPa})$. For testing utilization of electron acceptors, molecular oxygen $\left(0 \cdot 1\right.$ or $1 \% \mathrm{O}_{2}$ in the gas phase) was examined with $\mathrm{MMJH}$ medium in the absence of nitrate under a $\mathrm{H}_{2} / \mathrm{CO}_{2}$ gas mixture and nitrate $(10 \mathrm{mM})$, nitrite $(1$ or $5 \mathrm{mM})$, sulfite $(2$ or $10 \mathrm{mM})$, thiosulfate $(10 \mathrm{mM})$, tetrathionate $(10 \mathrm{mM})$, ferric citrate $(20 \mathrm{mM})$, ferrihydrite $(20 \mathrm{mM})$, selenate $(5 \mathrm{mM})$, arsenate $(5 \mathrm{mM})$ or fumarate $(10 \mathrm{mM})$ were tested with $\mathrm{MMJH}$ medium under $\mathrm{H}_{2} / \mathrm{CO}_{2}(80: 20, \mathrm{v} / \mathrm{v} ; 300 \mathrm{kPa})$. None of the electron donors other than $\mathrm{H}_{2}$ supported growth of strain EP1-55-1\% ${ }^{\mathrm{T}}$, while molecular oxygen $\left(1 \% \mathrm{O}_{2}\right)$ or nitrate $(10 \mathrm{mM})$ was able to serve as the primary electron acceptor, 
Table 1. Comparison of properties among Hydrogenimonas thermophila gen. nov., sp. nov., N. lithotrophica and C. hydrogeniphilus

Strains: 1, H. thermophila EP1-55-1\% ${ }^{\mathrm{T}}$; 2, N. lithotrophica $525^{\mathrm{T}}$ (data from Miroshnichenko et al., 2002); 3, C. hydrogeniphilus AM1116 ${ }^{\mathrm{T}}$ (data from Alain et al., 2002). ND, Not determined.

\begin{tabular}{|c|c|c|c|}
\hline Characteristic & 1 & 2 & 3 \\
\hline Cell shape & Short rod or spherical & Short rod & Short rod \\
\hline \multicolumn{4}{|l|}{ Temperature for growth: $\left({ }^{\circ} \mathrm{C}\right)$} \\
\hline Range & $35-65$ & $37-68$ & $50-70$ \\
\hline Optimum & 55 & 53 & 60 \\
\hline Doubling time under optimal conditions (min) & 70 & 140 & 90 \\
\hline \multicolumn{4}{|l|}{$\mathrm{pH}$ for growth: } \\
\hline Range & $4 \cdot 9-7 \cdot 2$ & $6 \cdot 4-7 \cdot 4$ & $5 \cdot 5-7 \cdot 5$ \\
\hline Optimum & $5 \cdot 9$ & $6 \cdot 8-7 \cdot 0$ & $5 \cdot 5-6 \cdot 0$ \\
\hline \multicolumn{4}{|l|}{$\mathrm{NaCl}$ concentration for growth: $(\%, w / v)$} \\
\hline Range & $1 \cdot 6-5 \cdot 6$ & $0 \cdot 8-5 \cdot 0$ & $1 \cdot 0-4 \cdot 0$ \\
\hline Optimum & $3 \cdot 2$ & 3 & $2 \cdot 0-2 \cdot 5$ \\
\hline Microaerobic growth & $+\left(\right.$ up to $\left.2 \% \mathrm{O}_{2}\right)$ & - & - \\
\hline \multicolumn{4}{|l|}{ Carbon sources other than $\mathrm{CO}_{2}$ : } \\
\hline Formate & - & + & - \\
\hline Complex organic substrates & - & - & + \\
\hline \multicolumn{4}{|l|}{ Electron donors other than $\mathrm{H}_{2}$ : } \\
\hline Formate & - & + & - \\
\hline \multicolumn{4}{|l|}{ Electron acceptors other than $S^{0}$ : } \\
\hline $\mathrm{O}_{2}$ & + & - & - \\
\hline Nitrate & + & - & + \\
\hline Sulfite & - & + & - \\
\hline Cystine & - & - & + \\
\hline \multicolumn{4}{|l|}{ Nitrogen sources: } \\
\hline Ammonium & + & + & ND \\
\hline Nitrate & + & + & ND \\
\hline $\mathrm{G}+\mathrm{C}$ content of genomic DNA $(\mathrm{mol} \%)$ & $34 \cdot 6$ & $34 \cdot 7$ & 29 \\
\hline
\end{tabular}

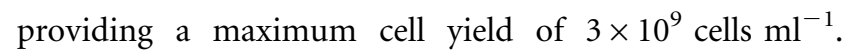
Elemental sulfur $(3 \%, w / v)$ gave a slightly lower cell yield $\left(1 \times 10^{9}\right.$ cells $\left.\mathrm{ml}^{-1}\right)$. Potential nutrients required for growth, such as selenite, tungstate and vitamins, were examined with MMJH medium with and without the specified nutrients. The nitrogen source $\left(\mathrm{NH}_{4} \mathrm{Cl}, \mathrm{NaNO}_{2}, \mathrm{~N}_{2}\right.$ or $\left.\mathrm{NaNO}_{3}\right)$ for growth was also examined with $\mathrm{MMJH}$ medium lacking all nitrogen sources. Strain EP1-55-1\% ${ }^{\mathrm{T}}$ utilized nitrate and ammonium as nitrogen sources and not nitrite or molecular nitrogen. Selenium, tungsten and vitamins were not required for growth. However, when the concentration of calcium chloride in $\mathrm{MMJH}$ medium was reduced from 0.08 to $0.01 \%(\mathrm{w} / \mathrm{v})$, the maximum cell yield of strain EP1-55-1\% ${ }^{\mathrm{T}}$ was reduced to $8 \cdot 0 \times 10^{8}$ cells $\mathrm{ml}^{-1}$. A relatively high concentration of calcium was stimulatory for growth of strain EP1-55-1\% ${ }^{\mathrm{T}}$. These results indicated that strain EP $1-55-1 \%{ }^{\mathrm{T}}$ is a strict chemolithoautotroph utilizing hydrogen as the sole energy source, molecular oxygen (up to $2 \%, v / v)$, nitrate and elemental sulfur as electron acceptors and carbon dioxide as the sole carbon source for growth. The microaerobic growth and utilization of molecular oxygen as an electron acceptor by strain EP1-55-1\% ${ }^{\mathrm{T}}$ represent a marked difference from the strictly anaerobic energy metabolisms of N. lithotrophica $525^{\mathrm{T}}$ (Miroshnichenko et al., 2002) and C. hydrogeniphilus AM1116 ${ }^{\mathrm{T}}$ (Alain et al., 2002) (Table 1).

The time-course of reduction of nitrate and elemental sulfur and the concomitant bacterial growth of strain EP1-55$1 \%{ }^{\mathrm{T}}$ were examined with MMJH medium under anaerobic conditions in the absence of ammonium and nitrate (Fig. 2). The concentrations of nitrate and nitrite were analysed by ion chromatography using a Shim-pack IC column (Shimadzu); the production of $\mathrm{N}_{2}, \mathrm{~N}_{2} \mathrm{O}$ and $\mathrm{H}_{2} \mathrm{~S}$ in the gas phase during growth was monitored using a Micro GC CP2002 gas chromatograph (GL Sciences). Nessler's reagent was employed to measure the ammoniumion concentration in the medium (Allen et al., 1974). Consumption of nitrate and production of ammonium occurred during growth of strain EP1-55-1\% ${ }^{\mathrm{T}}$ when nitrate was given as the sole electron acceptor (Fig. 2). Production of nitrite, $\mathrm{N}_{2}$ and $\mathrm{N}_{2} \mathrm{O}$ was not observed during growth. Hydrogen sulfide was accumulated in the gas phase depending on growth with elemental sulfur as sole electron acceptor (data not shown). Control (uninoculated) medium did not exhibit either nitrate or elemental sulfur reduction. 


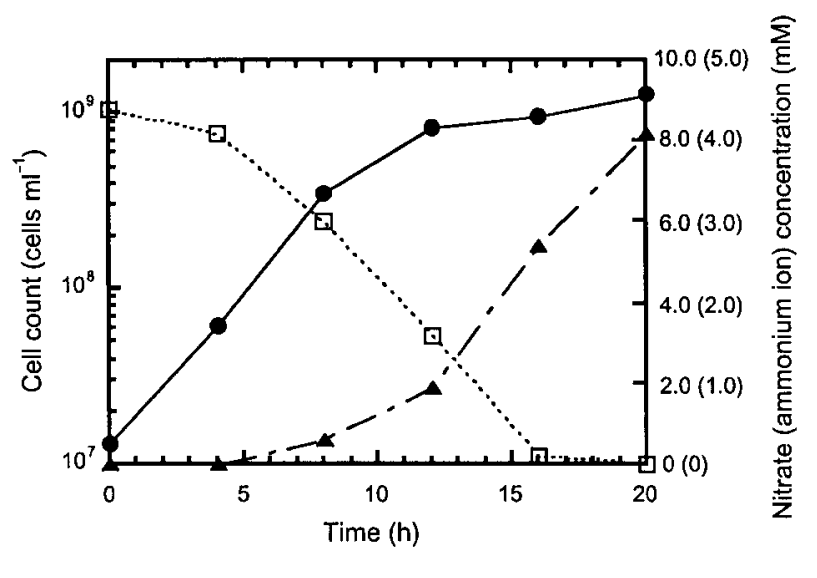

Fig. 2. Time-course of the reduction of nitrate $(\square)$, the production of ammonium $(\boldsymbol{\Lambda})$ and concomitant bacterial growth $(\boldsymbol{\theta})$ of strain EP1-55-1\% $\%^{\top}$.

Thus, strain EP1-55-1\% ${ }^{\mathrm{T}}$ was found to be a respiratory hydrogen-oxidizing, oxygen-, nitrate- or sulfur-reducing chemolithoautotroph.

Strain EP1-55-1\% ${ }^{\mathrm{T}}$ was found to be sensitive to a variety of antibiotics, including chloramphenicol, streptomycin, kanamycin, ampicillin and rifampicin (all at $50 \mu \mathrm{g} \mathrm{ml}^{-1}$; data not shown). Antibiotic susceptibility was similar for strain EP1-55-1\% ${ }^{\mathrm{T}}$ and N. lithotrophica $525^{\mathrm{T}}$ (Miroshnichenko et al., 2002), but C. hydrogeniphilus AM1116 ${ }^{\mathrm{T}}$ (Alain et al., 2002) was resistant to kanamycin $\left(100 \mu \mathrm{g} \mathrm{ml}^{-1}\right)$.

\section{Fatty acid analysis}

The cellular fatty acid composition was analysed with cells grown in $\mathrm{MMJH}$ medium at $55^{\circ} \mathrm{C}$ in the late-exponential growth phase. Lyophilized cells (100 mg) were placed in a Teflon-lined, screw-capped tube containing $3 \mathrm{ml}$ anhydrous methanolic $\mathrm{HCl}$ and heated at $100{ }^{\circ} \mathrm{C}$ for $3 \mathrm{~h}$. Extraction and analysis of fatty acid methyl esters were as described previously (Takai et al., 2003b). The major cellular fatty acids of strain EP1-55-1\% ${ }^{\mathrm{T}}$ were $\mathrm{C}_{11: 0}(2 \cdot 2 \%), \mathrm{C}_{12: 0}$ $(3 \cdot 0 \%), \mathrm{C}_{14: 0}(4 \cdot 7 \%), 3-\mathrm{OH}-\mathrm{C}_{14: 0}(2 \cdot 8 \%), \mathrm{C}_{16: 0}(37 \cdot 4 \%)$, $\mathrm{C}_{16: 1}(28 \cdot 8 \%), \mathrm{C}_{18: 0}(1 \cdot 0 \%)$ and $\mathrm{C}_{18: 1}(20 \cdot 0 \%)$. This composition was similar to that of a recently described mesophilic isolate, Sulfurimonas autotrophica $\mathrm{OK}-10^{\mathrm{T}}$, from a deep-sea hydrothermal system in the Okinawa Trough (Inagaki et al., 2003).

\section{Nucleic acid analyses}

Genomic DNA of strain EP1-55-1\% ${ }^{\mathrm{T}}$ was prepared as described by Marmur \& Doty (1962). The G $+C$ content of the DNA was determined by direct analysis of deoxyribonucleotides by using HPLC (Tamaoka \& Komagata, 1984). The $\mathrm{G}+\mathrm{C}$ content of the genomic DNA of strain EP1$55-1 \%{ }^{\mathrm{T}}$ was $34.6 \mathrm{~mol} \%$, which is similar to that of N. lithotrophica $525^{\mathrm{T}}(34 \cdot 7 \mathrm{~mol} \%$; Miroshnichenko et al.,
2002) but higher than that of C. hydrogeniphilus AM1116 ${ }^{\mathrm{T}}$ (29 mol\%; Alain et al., 2002) (Table 1).

The 16S rRNA gene (rDNA) was amplified by PCR using primers Bac 27F and 1492R (DeLong, 1992; Lane, 1985), as described previously (Takai et al., 2001). The nearly complete 16S rDNA sequence (1422 bp) of strain EP1-55$1 \%{ }^{\mathrm{T}}$ was obtained by direct sequencing of both strands, using the dideoxynucleotide chain-termination method with a DNA sequencer (model 3100; Perkin Elmer/Applied Biosystems). The rDNA sequence was analysed using the gapped-BLAST search algorithm (Altschul et al., 1997; Benson et al., 1998) and found to be most closely related $(99 \cdot 7 \%)$ to the sequences of strain EP365-55-1\% (isolated from the same deep-sea hydrothermal field; Takai et al., 2003a) and strain BKB55-1 [94.4\%; isolated from the Iheya North site in the Okinawa Trough (Takai et al., 2003a)] and to have similarity to sequences of the slightly thermophilic Sulfurospirillum strain EX-18.1 (91·2\%) and strain Am-N (90.8\%) (isolated from East-Pacific Rise deep-sea hydrothermal vent sites; Campbell et al., 2001). Strain EP1$55-1 \%^{\mathrm{T}}$ showed only a distant relationship (less than $90 \%$ similarity) to any strain of presently known members of the $\varepsilon$-Proteobacteria. The nearly complete sequence was realigned manually to $16 \mathrm{~S}$ rDNA data from the Ribosomal Database Project II (Maidak et al., 2000) on the basis of the alignments determined using the SEQUENCE ALIGNER program of Ribosomal Database Project II. Phylogenetic analyses were restricted to nucleotide positions that could be aligned unambiguously. Evolutionary distance-matrix analysis (using the Kimura two-parameter method, the least-squares distance method and a transition/transversion rate of $2 \cdot 0$ ) and neighbour-joining analysis were performed using the PHYLIP package, version 3.5 (Felsenstein, 1993) (Fig. 3). Bootstrap analysis was performed to provide confidence estimates for phylogenetic tree topologies. The phylogenetic tree indicated that strain EP1-55-1\% ${ }^{\mathrm{T}}$ represented the first strain for which taxonomic properties have been characterized within the previously uncultivated phylogroup classified within the uncultivated group A E-proteobacteria (Corre et al., 2001; Takai et al., 2003a) (Fig. 3).

\section{Comparison with related genera}

Phylogenetic analysis indicates that strain EP1-55-1\% ${ }^{\mathrm{T}}$ is distantly related to any previously described members of the $\varepsilon$-Proteobacteria. Other than strain EP1-55-1\% ${ }^{\mathrm{T}}$, several deep-sea hydrothermal vent $\varepsilon$-proteobacteria from the Central Indian Ridge Kairei hydrothermal field and the Okinawa Trough Iheya North site are affiliated with this phylogroup, together with a variety of environmental rDNA clones obtained from the Mid-Atlantic-Ridge deepsea hydrothermal system (Takai et al., 2003a). All thermophilic strains capable of growth at $55^{\circ} \mathrm{C}$ isolated to date from deep-sea hydrothermal environments are classified within either group A or group D (Takai et al., 2003a). Hence, these phylogroups might be characterized as a thermophilic lineage within the $\varepsilon$-Proteobacteria, representing at 


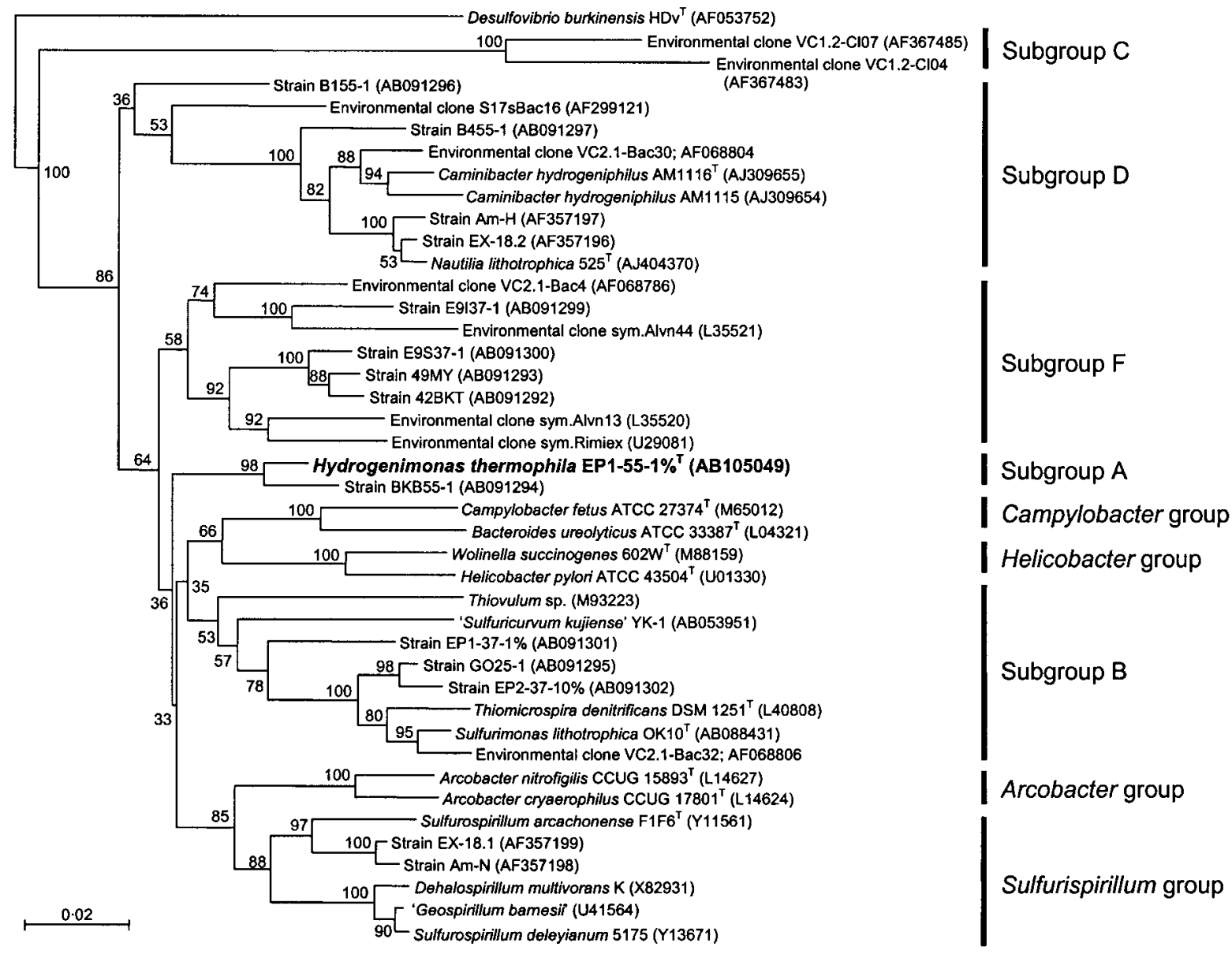

Fig. 3. Phylogenetic tree of representative $\varepsilon$-proteobacterial strains and environmental rDNA clones potentially related to strain EP1-55-1\% $\%^{\top}$, inferred from $16 \mathrm{~S}$ rDNA sequences by using the neighbour-joining method on 1011 homologous sequence positions for each organism. Numbers at nodes represent bootstrap values (100 replicates). The scale bar indicates 2 substitutions per 100 nucleotides.

least a new family level of taxa indigenous to the global deep-sea hydrothermal systems.

Only two thermophilic members of the e-Proteobacteria, N. lithotrophica $525^{\mathrm{T}}$ (Miroshnichenko et al., 2002) and C. hydrogeniphilus $\mathrm{AM} 1116^{\mathrm{T}}$ (Alain et al., 2002), have been described previously, and, on the basis of both phylogenetic characterization and physiological properties, strain EP1$55-1 \%^{\mathrm{T}}$ can be easily distinguished from them (Table 1). The genera Nautilia and Caminibacter are composed of strictly anaerobic mixotrophs capable of utilizing organic compounds as carbon sources. N. lithotrophica $525^{\mathrm{T}}$ (Miroshnichenko et al., 2002) uses formate as an energy source. Strain EP1-55-1\% ${ }^{\mathrm{T}}$ is able to grow under microaerobic conditions (up to $2 \% \mathrm{O}_{2}$ ) and is a strictly hydrogen-oxidizing chemolithoautotroph. Although all three thermophiles can use molecular hydrogen as the primary energy source, their utilization profiles for electron acceptors differ. The electron acceptors for strain EP1$55-1 \%{ }^{\mathrm{T}}$ are oxygen, nitrate and elemental sulfur. C. hydrogeniphilus AM1116 ${ }^{\mathrm{T}}$ (Alain et al., 2002) can utilize elemental sulfur, nitrate and, to lesser extent, cystine, while N. lithotrophica $525^{\mathrm{T}}$ (Miroshnichenko et al., 2002) primarily uses elemental sulfur or, alternatively, sulfite (Table 1). These are probably strong metabolic characteristics that differentiate strain $\mathrm{EP} 1-55-1 \%^{\mathrm{T}}$ from the genera within group $\mathrm{D}$ of the $\varepsilon$-Proteobacteria. On the basis of these physiological and molecular properties of strain EP1-55-1\% ${ }^{\mathrm{T}}$, we propose a new genus, Hydrogenimonas gen. nov., with the type species Hydrogenimonas thermophila sp. nov.

\section{Description of Hydrogenimonas gen. nov.}

Hydrogenimonas (Hy.dro.ge.ni.mo' nas. N.L. neut. n. hydrogenium hydrogen; Gr. n. monas a unit, monad; N.L. fem. n. Hydrogenimonas hydrogen monad).

Short rods, highly motile via a polar flagellum. Gramnegative. Anaerobic to microaerobic. Thermophilic. Strictly chemolithoautotrophic. Able to utilize molecular hydrogen as an electron acceptor and molecular oxygen, nitrate or elemental sulfur as electron acceptors. $\mathrm{NaCl}$ absolutely 
required for growth. Relatively high concentrations of calcium stimulate growth. The $\mathrm{G}+\mathrm{C}$ content of the genomic DNA is about $35 \mathrm{~mol} \%$. Major cellular fatty acids are $\mathrm{C}_{16: 0}, \mathrm{C}_{16: 1}$ and $\mathrm{C}_{18: 1}$. On the basis of 16S rRNA gene analysis, the genus Hydrogenimonas is distantly related to any previously described genera within the $\varepsilon$ Proteobacteria, representing a potential new family level of taxon. Members of the genus occur in global, deep-sea, hydrothermal systems. The type species is Hydrogenimonas thermophila.

\section{Description of Hydrogenimonas thermophila sp. nov.}

Hydrogenimonas thermophila (ther.mo'phil.a. Gr. adj. thermus hot; Gr. adj. philos loving; N.L. fem. adj. thermophila heat-loving).

Exhibits the following properties in addition to those given in the genus description. Cells have a mean length of $1 \cdot 5-3 \cdot 5 \mu \mathrm{m}$ and a width of approx. $0 \cdot 7-1 \cdot 0 \mu \mathrm{m}$. Cells occur singly. Tolerates up to $2 \% \mathrm{O}_{2}$ in the gas phase. The temperature range for growth is $35-65^{\circ} \mathrm{C}$ (optimum at $55^{\circ} \mathrm{C}$ ). The $\mathrm{pH}$ range for growth is $4 \cdot 9-7 \cdot 2$ (optimum at $\mathrm{pH} 5 \cdot 9) . \mathrm{NaCl}$ in the concentration range $16-56 \mathrm{gl}^{-1}$ is an absolute growth requirement; optimum growth occurs at $32 \mathrm{~g} \mathrm{l}^{-1}$. Nitrate and elemental sulfur are respectively reduced to ammonium and hydrogen sulfide during growth. Nitrate or ammonium is required as a nitrogen source. Vitamins, selenium and tungsten are not required for growth. The major cellular fatty acids are $\mathrm{C}_{11: 0}(2 \cdot 2 \%)$, $\mathrm{C}_{12: 0}(3 \cdot 0 \%), \mathrm{C}_{14: 0}(4 \cdot 7 \%), 3-\mathrm{OH}-\mathrm{C}_{14: 0}(2 \cdot 8 \%), \mathrm{C}_{16: 0}$ $(37 \cdot 4 \%), \mathrm{C}_{16: 1}(28 \cdot 8 \%), \mathrm{C}_{18: 0}(1 \cdot 0 \%)$ and $\mathrm{C}_{18: 1}(20 \cdot 0 \%)$. The $\mathrm{G}+\mathrm{C}$ content of the DNA is $34 \cdot 6 \mathrm{~mol} \%$ (by HPLC).

The type strain, EP1-55-1\% ${ }^{\mathrm{T}}\left(=\mathrm{JCM} 11971^{\mathrm{T}}=\right.$ ATCC BAA$\left.737^{\mathrm{T}}\right)$, was isolated from an in-situ colonization system deployed in the black smoker vent emission $\left(>250{ }^{\circ} \mathrm{C}\right)$ at the Kairei Field on the Central Indian Ridge, Indian Ocean.

\section{Acknowledgements}

We would like to thank Dr Katsuyuki Uematsu for assistance with the preparation of electron micrographs. We are very grateful to the $R / V$ Yokosuka and the Shinkai 6500 operation teams for helping us to collect deep-sea hydrothermal vent samples.

\section{References}

Alain, K., Querellou, J., Lesongeur, F., Pignet, P., Crassous, P., Raguénès, G., Cueff, V. \& Cambon-Bonavita, M.-A. (2002). Caminibacter hydrogeniphilus gen. nov., sp. nov., a novel thermophilic, hydrogen-oxidizing bacterium isolated from an East Pacific Rise hydrothermal vent. Int J Syst Evol Microbiol 52, 1317-1323.

Allen, S. E., Grimshaw, H. M., Parkinson, J. A. \& Quarmby, C. (1974). Inorganic constituents: nitrogen. In Chemical Analysis of Ecological Materials, pp. 184-206. Edited by S. E. Allen. London: Blackwell Scientific.

Altschul, S. F., Madden, T. L., Schäffer, A. A., Zhang, J., Zhang, Z., Miller, W. \& Lipman, D. J. (1997). Gapped BLAST and PSI-BLAST: a new generation of protein database search programs. Nucleic Acids Res 25, 3389-3402.

Balch, W. E., Fox, G. E., Magrum, L. J., Woese, C. R. \& Wolfe, R. S. (1979). Methanogens: reevaluation of a unique biological group. Microbiol Rev 43, 260-296.

Benson, D. A., Boguski, M. S., Lipman, D. J., Ostell, J. \& Ouellette, B. F. F. (1998). Genbank. Nucleic Acids Res 26, 1-7.

Campbell, B. J., Jeanthon, C., Kostka, J. E., Luther, G. W., III \& Cary, S. C. (2001). Growth and phylogenetic properties of novel bacteria belonging to the epsilon subdivision of the Proteobacteria enriched from Alvinella pompejana and deep-sea hydrothermal vents. Appl Environ Microbiol 67, 4566-4572.

Cary, S. C., Cottrell, M. T., Stein, J. L., Camacho, F. \& Desbruyeres, D. (1997). Molecular identification and localization of filamentous symbiotic bacteria associated with the hydrothermal vent annelid Alvinella pompejana. Appl Environ Microbiol 63, 1124-1130.

Corre, E., Reysenbach, A.-L. \& Prieur, D. (2001). $\varepsilon$-Proteobacterial diversity from a deep-sea hydrothermal vent on the Mid-Atlantic Ridge. FEMS Microbiol Lett 205, 329-335.

DeLong, E. F. (1992). Archaea in coastal marine environments. Proc Natl Acad Sci U S A 89, 5685-5689.

Felsenstein, J. (1993). PHYLIP: phylogenetic inference package, version 3.5. Distributed by the author. Department of Genetics, University of Washington, Seattle, USA.

Gamo, T., Chiba, H., Yamanaka, T. \& 9 other authors (2001). Chemical characteristics of newly discovered black smoker fluids and associated hydrothermal plumes at the Rodriguez Triple Junction, Central Indian Ridge. Earth Planet Sci Lett 193, 371-379.

Hashimoto, J., Ohta, S., Gamo, T. \& 7 other authors (2001). First hydrothermal vent communities from the Indian Ocean discovered. Zool Sci 18, 717-721.

Inagaki, F., Takai, K., Kobayashi, H., Nealson, K. H. \& Horikoshi, K. (2003). Sulfurimonas autotrophica gen. nov., sp. nov., a novel sulfuroxidizing $\varepsilon$-proteobacterium isolated from hydrothermal sediments in the mid-Okinawa Trough. Int J Syst Evol Microbiol 53, 1801-1805.

Lane, D. J. (1985). 16S/23S sequencing. In Nucleic Acid Techniques in Bacterial Systematics, pp. 115-176. Edited by E. Stackebrandt \& M. Goodfellow. New York: Wiley.

Longnecker, K. \& Reysenbach, A.-L. (2001). Expansion of the geographic distribution of a novel lineage of $\varepsilon$-Proteobacteria to a hydrothermal vent site on the southern East Pacific Rise. FEMS Microbiol Lett 35, 287-293.

Maidak, B. L., Cole, J. R., Lilburn, T. G. \& 9 other authors (2000). The RDP (Ribosomal Database Project) continues. Nucleic Acids Res 28, 173-174.

Marmur, J. \& Doty, P. (1962). Determination of the base composition of deoxyribonucleic acid from its thermal denaturation temperature. J Mol Biol 5, 109-118.

Miroshnichenko, M. L., Kostrikina, N. A., L'Haridon, S., Jeanthon, C., Hippe, H., Stackebrandt, E. \& Bonch-Osmolovskaya, E. A. (2002). Nautilia lithotrophica gen. nov., sp. nov., a thermophilic sulfurreducing $\varepsilon$-proteobacterium isolated from a deep-sea hydrothermal vent. Int J Syst Evol Microbiol 52, 1299-1304.

Moyer, C. L., Dobbs, F. C. \& Karl, D. M. (1995). Phylogenetic diversity of the bacterial community from a microbial mat at an active, hydrothermal vent system, Loihi Seamount, Hawaii. Appl Environ Microbiol 61, 1555-1562.

Porter, K. G. \& Feig, Y. S. (1980). The use of DAPI for identifying and counting microflora. Limnol Oceanogr 25, 943-948.

Reysenbach, A.-L., Longnecker, K. \& Kirshtein, J. (2000). Novel bacterial and archaeal lineages from an in situ growth chamber 
deployed at a Mid-Atlantic Ridge hydrothermal vent. Appl Environ Microbiol 66, 3798-3806.

Sako, Y., Takai, K., Ishida, Y., Uchida, A. \& Katayama, Y. (1996). Rhodothermus obamensis sp. nov., a modern lineage of extremely thermophilic marine bacteria. Int J Syst Bacteriol 46, 1099-1104.

Takai, K. \& Fujiwara, Y. (2002). Hydrothermal vents: biodiversity in deep-sea hydrothermal vents. In Encyclopedia of Environmental Microbiology, pp. 1604-1617. Edited by G. Bitton. New York: Wiley.

Takai, K. \& Horikoshi, K. (2000). Thermosipho japonicus sp. nov., an extremely thermophilic bacterium isolated from a deep-sea hydrothermal vent in Japan. Extremophiles 4, 9-17.

Takai, K., Inoue, A. \& Horikoshi, K. (1999). Thermaerobacter marianensis gen. nov., sp. nov., an aerobic extremely thermophilic marine bacterium from the $11000 \mathrm{~m}$ deep Mariana Trench. Int J Syst Bacteriol 49, 619-628.

Takai, K., Komatsu, T. \& Horikoshi, K. (2001). Hydrogenobacter subterraneus sp. nov., an extremely thermophilic, heterotrophic bacterium unable to grow on hydrogen gas, from deep subsurface geothermal water. Int J Syst Evol Microbiol 51, 1425-1435.
Takai, K., Inoue, A. \& Horikoshi, K. (2002). Methanothermococcus okinawensis sp. nov., a thermophilic methane-producing archaeon isolated from a Western Pacific deep-sea hydrothermal vent system. Int J Syst Evol Microbiol 52, 1089-1095.

Takai, K., Inagaki, F., Nakagawa, S., Hirayama, H., Nunoura, T., Sako, Y., Nealson, K. H. \& Horikoshi, K. (2003a). Isolation and phylogenetic diversity of members of previously uncultivated $\varepsilon$ Proteobacteria in deep-sea hydrothermal fields. FEMS Microbiol Lett 218, 167-174.

Takai, K., Kobayashi, H., Nealson, K. H. \& Horikoshi, K. (2003b). Deferribacter desulfuricans sp. nov., a novel sulfur-, nitrate- and arsenate-reducing thermophile isolated from a deep-sea hydrothermal vent. Int J Syst Evol Microbiol 53, 839-846.

Tamaoka, J. \& Komagata, K. (1984). Determination of DNA base composition by reversed-phase high-performance liquid chromatography. FEMS Microbiol Lett 25, 125-128.

Zillig, W., Holz, I., Janekovic, D. \& 7 other authors (1990). Hyperthermus butylicus, a hyperthermophilic sulfur-reducing archaebacterium that ferments peptides. J Bacteriol 172, 3959-3965. 